\title{
Profil Infeksi Plasmodium, Anemia dan Status Nutrisi pada Malaria Anak di RSUD Scholoo Keyen, Kabupaten Sorong Selatan
}

\author{
Reza Abdussalam, ${ }^{*}$ Rosaline NI Krimadi, ${ }^{* *}$ Rustam Siregar, ${ }^{*}$ Endang Dewi Lestari, ${ }^{*}$ Harsono Salimo \\ *Departemen Ilmu Kesehatan Anak Fakultas Kedokteran Universitas Sebelas Maret, RSUD Dr. Moewardi Surakarta, \\ **RSUD Scholoo Keyen, Kabupaten Sorong Selatan
}

\begin{abstract}
Latar belakang. Angka kesakitan malaria di Indonesia masih cukup tinggi. Masalah pada malaria adalah antara lain kejadian anemia pada infeksi plasmodium disebabkan hemolisis sel darah merah dan penurunan eritropoesis, sedangkan hubungan antara infeksi plasmodium dengan malnutrisi masih harus diklarifikasi.

Tujuan. Menilai proporsi anemia dan status nutrisi pada malaria anak.

Metode. Penelitian potong lintang dilakukan selama 2 bulan (Mei-Juni 2015) pada 45 anak dengan diagnosis malaria yang dirawat inap dan rawat jalan di RSUD Scholoo Keyen. Diagnosis malaria ditegakkan berdasarkan pemeriksaan sediaan darah tebal dan tipis. Hasil. Terdapat 45 anak, 25 laki-laki dan 20 perempuan. Rentang usia terbanyak 1-5 tahun. Ditemukan 30 anak dengan malaria tropikana. Didapatkan 25 anak dengan kadar hemoglobin antara (8-10) g/dL. Status nutrisi ditemukan 19 anak wasting dan 16 stunted. Kesimpulan. Malaria yang paling banyak ditemukan adalah malaria tropikana, disertai kejadian penyerta seperti anemia dan gizi kurang. Sari Pediatri 2016;17(6):446-9.
\end{abstract}

Kata kunci: plasmodium, anemia, status gizi

\section{Plasmodium Infection Profile, Anemia and Nutritional Status in Children with Malaria in Scholoo Keyen Hospital in South Sorong}

Reza Abdussalam, ${ }^{*}$ Rosaline NI Krimadi, ${ }^{* *}$ Rustam Siregar, ${ }^{*}$ Endang Dewi Lestari, ${ }^{*}$ Harsono Salimo

Background. In Indonesia still has high incidence of malaria. Anemia in plasmodium infection is due to red blood cell hemolysis and decreased erytropoesis, while the correlation of plasmodium plasmodium infection with malnutrition must be clarified.

Objective. This study was conducted to analyse the correlation between plasmodium infection, anemia, and nutritional status in pediatric patients with malaria in South Sorong.

Methods. This cross sectional study was performed between from May through June 2015. There were 45 children diagnosesd with malaria who were hospitalized and out patients in Scholoo Keyen Hospital. Malaria diagnosis was established by examining the thin and thick blood smear slides.

Result. There were 45 children included in this study, 25 boys and 20 girls. Most (53.3\%) children affected were between $1-5$ years old ( 24 children). The most $(66.7 \%)$ common type of malaria was due to falciparum (tropical) malaria (30 children). Twenty five $(55.6 \%)$ children had hemoglobin level between 8 to $10 \mathrm{gram} / \mathrm{dl}$. Wasting was found in $19(42.2 \%)$ children, while stunting was observed in $16(35.6 \%)$ children.

Conclusion. The most common type of malaria found is Tropicana malaria, with coexisting insidence of anemia and malnourishment. Sari Pediatri 2016;17(6):446-9.

Keyword: plasmodium, anemia, nutritional status

\footnotetext{
Alamat korespondensi: Prof. DR. Dr. Harsono Salimo, Sp.A(K). Bagian IKA FK-UNS/RS Dr. Moewardi. Jl. Dr. Sutomo 1, Surakarta.
}

Tel.+62-271-666866 E-mail: harsonosalimo@idai.or.id, harsa_5id@yahoo.com 
$\mathrm{D}$ i Indonesia, malaria sampai saat ini masih merupakan masalah kesehatan masyarakat. Angka kesakitan malaria masih cukup tinggi, terutama pada daerah di luar pulau Jawa dan Bali. Pada daerah tersebut masih sering terjadi wabah malaria yang menimbulkan banyak kematian. Malaria merupakan penyakit infeksi akut atau kronis yang disebabkan oleh plasmodium, ditandai dengan gejala demam rekuren, anemia, dan splenomegali. ${ }^{1}$

Insiden malaria penduduk Indonesia tahun 2007 dan 2013, berturut-turut adalah 2,9\% dan 1,9\%. Sementara itu, prevalensi malaria tahun 2013, 6\%. Insiden dan prevalensi malaria tertinggi terdapat di provinsi Papua, Nusa Tenggara Timur, Papua Barat, Sulawesi Tengah, dan Maluku. Parasit plasmodium seringkali menyebabkan anemia sebagai akibat hiperhemolisis sel darah merah dan menurunkan proses eritropoesis. Mekanisme terjadinya anemia selama infeksi plasmodium sudah dapat dibuktikan, sedangkan hubungan antara infeksi plasmodium dengan malnutrisi masih harus diklarifikasi. ${ }^{2,3}$ Penelitian ini ditujukan untuk menilai proporsi infeksi plasmodium, anemia, dan status nutrisi pada malaria anak di kabupaten Sorong Selatan.

\section{Metode}

Studi potong lintang digunakan pada penelitian yang dilakukan selama 2 bulan (Mei sampai dengan Juni 2015) terdapat 45 anak dengan diagnosis malaria yang menjalani rawat inap dan rawat jalan di Bagian Anak RSUD Scholoo Keyen. Rentang usia 1 bulan sampai dengan 18 tahun. Diagnosis malaria ditegakkan melalui pemeriksaan sediaan darah tebal dan tipis untuk menemukan parasit dan spesies malaria.

Semua anak yang didiagnosis malaria dilakukan pemeriksaan berat badan, tinggi badan yang disesuaikan dengan umur serta jenis kelamin dan dimasukkan data sesuai dengan grafik antropometri. Untuk anak kurang dari 5 tahun menggunakan grafik antropometri WHO tahun 2005. Sebaliknya, anak usia 5 sampai 18 tahun digunakan grafik antropometri CDC tahun 2000. Subjek juga dilakukan pemeriksaan hemoglobin, hematokrit, jumlah sel darah merah, MCV dan MCHC.

\section{Hasil}

Empatpuluh lima anak mengikuti penelitian ini,
Tabel 1. Karakteristik subjek penelitian

\begin{tabular}{lc}
\hline Variabel & Jumlah $\mathrm{n}=45$ \\
\hline Bulan & \\
Mei 2015 & 23 \\
Juni 2015 & 22 \\
Jenis kelamin & \\
$\quad$ Laki-laki & 25 \\
$\quad$ Perempuan & 20 \\
Kelompok usia (tahun) & \\
$\quad<1$ & 12 \\
$1-5$ & 24 \\
$>5$ & 9 \\
Jenis malaria & \\
Tertiana & 15 \\
Tropikana & 30 \\
\hline
\end{tabular}

dengan perbandingan 25 anak laki-laki dan 20 anak perempuan. Kelompok usia paling banyak yaitu 1-5 tahun sebanyak 24 anak (53,3\%). Jenis malaria yang paling banyak ditemukan adalah malaria tropikana 30 anak $(67,7 \%)$

Dari 45 subyek penelitian, 25 anak mempunyai kadar hemoglobin paling banyak, antara 8 sampai dengan $10 \mathrm{~g} / \mathrm{dL}$. Kadar MCV kurang dari $80 \mathrm{fl}$ ditemukan pada 35 anak dan kadar $\mathrm{MCH}$ kurang dari $28 \mathrm{~g} / \mathrm{dL}$ ditemukan pada 34 anak.

Sepuluh anak kurang dari 5 tahun mempunyai status gizi wasting dengan status gizi $\mathrm{BB} / \mathrm{U}-3 \mathrm{SD}<\mathrm{ZS}<-$ 2SD 10 anak, stunted dengan statuts gizi $\mathrm{TB} / \mathrm{U}$ $-3 \mathrm{SD}<\mathrm{ZS}<-2 \mathrm{SD} 6$ anak, dan gizi kurang menurut antropometris 8 anak. Anak lebih dari 5 tahun keadaan wasting dengan status gizi $\mathrm{BB} / \mathrm{U} \mathrm{p} 3<\mathrm{BB} / \mathrm{U}<\mathrm{p} 10$ adalah 5 anak, stunted dengan status gizi $\mathrm{TB} / \mathrm{U} \mathrm{p} 3<\mathrm{TB} /$ $\mathrm{U}<\mathrm{p} 103$ anak, dan gizi kurang dengan $\mathrm{BB} / \mathrm{TB} \mathrm{p} 3<\mathrm{BB} /$ $\mathrm{TB}<\mathrm{p} 101$ anak.

Tabel 2. Hasil laboratorium

\begin{tabular}{lc}
\hline Laboratorium & Jumlah $\mathrm{n}=45$ \\
\hline Kadar hemoglobin $(\mathrm{g} / \mathrm{dL})$ & \\
$\quad>10$ & 15 \\
$8-10$ & 25 \\
$<8$ & 5 \\
Kadar MCV $(\mathrm{fl})$ & \\
$\quad<80$ & 35 \\
$>80 \mathrm{fl}$ & 10 \\
Kadar $<\mathrm{MCH}(\mathrm{g} / \mathrm{dL})$ & \\
$<28$ & 34 \\
$>28$ & 11 \\
\hline
\end{tabular}


Tabel 3. Status gizi (WHO, 2005)

\begin{tabular}{lc}
\hline Variabel & Jumlah $\mathrm{n}=36$ \\
\hline $\mathrm{BB} / \mathrm{U}$ & \\
$\mathrm{ZS}<-3 \mathrm{SD}$ & 3 \\
$-3<\mathrm{ZS}<-2 \mathrm{SD}$ & 10 \\
$\mathrm{ZS}>-2 \mathrm{SD}$ & 23 \\
$\mathrm{~TB} / \mathrm{U}$ & \\
$\mathrm{ZS}<-3 \mathrm{SD}$ & 5 \\
$-3 \mathrm{SD}<\mathrm{ZS}<-2 \mathrm{SD}$ & 6 \\
$\mathrm{ZS}>-2 \mathrm{SD}$ & 25 \\
$\mathrm{BB} / \mathrm{TB}$ & \\
$-3 \mathrm{SD}<\mathrm{ZS}<-2 \mathrm{SD}$ & 8 \\
$\mathrm{ZS}>-2 \mathrm{SD}$ & 28 \\
\hline
\end{tabular}

Tabel 4. Status gizi (CDC, 2000) $\mathrm{n}=9$

\begin{tabular}{lc}
\hline Variabel & Jumlah $\mathrm{n}=9$ \\
\hline $\mathrm{BB} / \mathrm{U}$ & \\
$<\mathrm{p} 3$ & 1 \\
$\mathrm{P} 3<\mathrm{BB} / \mathrm{U}<\mathrm{P} 10$ & 5 \\
$>\mathrm{p} 10$ & 3 \\
$\mathrm{~TB} / \mathrm{U}$ & \\
$<\mathrm{p} 3$ & 2 \\
$\mathrm{P} 3<\mathrm{TB} / \mathrm{U}<\mathrm{P} 10$ & 3 \\
$>\mathrm{p} 10$ & 4 \\
$\mathrm{BB} / \mathrm{TB}$ & \\
$<\mathrm{p} 3$ & 1 \\
$\mathrm{P} 3<\mathrm{BB} / \mathrm{TB}<\mathrm{P} 10$ & 0 \\
$>\mathrm{p} 10$ & 8 \\
&
\end{tabular}

\section{Pembahasan}

Malaria masih merupakan salah satu masalah kesehatan masyarakat yang dapat menyebabkan kematian terutama pada kelompok risiko tinggi, yaitu bayi dan anak. Insiden malaria di Indonesia pada tahun 2013 menurun dibanding tahun 2007, tetapi di Papua Barat mengalami peningkatan tajam. Lima provinsi dengan insiden dan prevalensi tertinggi adalah Papua (9,8\% dan 28,6\%), Nusa Tenggara Timur $(6,8 \%$ dan $23,3 \%)$, Papua Barat $(6,7 \%$ dan 19,4\%), Sulawesi Tengah (5,1\% dan 12,5\%), dan Maluku (3,8\% dan 10,7\%). ${ }^{4}$

Penelitian di RSUD Scholoo Keyen selama bulan Mei sampai Juni 2015 angka kejadian malaria pada anak adalah 45 (14,05\%), dari 323 pasien anak yang dilayani di bagian anak. Pada penelitian kami, pasien anak lakilaki lebih banyak dibanding perempuan, yaitu 25:20.
Sementara itu, menurut klasifikasi usia, <1, 1-5, dan $>5$ tahun berturut-turut 12, 24, dan 9 anak. Menurut data WHO tahun 2014, angka kematian malaria paling banyak di Benua Afrika, mencapai 78\% pada anak usia kurang dari 5 tahun. Dengan demikian, berdasarkan data yang kami peroleh bahwa lebih dari 50\% kasus malaria berumur kurang dari 5 tahun maka diperlukan pengawasan lebih lanjut. ${ }^{5}$

Penelitian kami juga menunjukkan jenis infeksi plasmodium terbanyak di Sorong Selatan adalah Plasmodium vivax dibanding jenis Plasmodium falciparum, yaitu 15:30 (33,3\% dan 67,7\%). Pemeriksaan deteksi plasmodium, dilakukan sediaan darah tebal dan darah tipis oleh analis dan spesialis patologi klinik yang terlatih. Hal tersebut sesuai dengan data dari Kementrian Kesehatan Republik Indonesia tahun 2008, jenis plasmodium yang berada di Indonesia, yaitu Plasmodium vivax dan Plasmodium falciparum. Selama pengamatan, kami tidak mendapatkan kejadian malaria berat pada subjek penelitian kami. ${ }^{4}$

Kejadian anemia dibuktikan dengan kadar hemoglobin kurang dari $10 \mathrm{~g} / \mathrm{dL}$, Didapatkan pada 30 anak; kadar MCV kurang dari 80/fl 35 anak dan kadar MCHC kurang dari $28 \mathrm{~g} / \mathrm{dL}$ pada 34 anak. Hal tersebut menunjukkan pasien dengan infeksi plasmodium seringkali juga disertai dengan keadaan anemia. Hal ini menunjukkan parasit Plasmodium menyebabkan anemia sebagai akibat hiperhemolisis sel darah merah dan menurunkan eritropoesis. Sesuai dengan penelitian Maketa $\mathrm{dkk}^{6}$ tahun 2015 yang melaporkan prevalensi anemia pada anak dengan infeksi plasmodium $61,6 \%$. Eritrosit hipokromok dan mikrositik yang diperlihatkan dari kadar MCV dan MCHC yang rendah masih dimungkinkan akibat defisiensi zat besi ataupun infeksi. Untuk membuktikan diperlukan pemeriksaan panel besi seperti kadar serum iron, kadar total iron binding cpacity (TIBC), dan kadar feritin untuk menyingkirkan anemia yang disebabkan oleh malaria.

Hampir 20\% dari total subjek penelitian dalam keadaan status gizi kurang. Keadaan tersebut dapat disebabkan asupan makanan yang kurang atau dapat disebabkan infeksi kronis yang diderita sehingga menyebabkan keadaan malnutrisi. Pada penelitian kami tidak dicantumkan pemeriksaan feses rutin untuk menyingkirkan infeksi parasit cacing, yang sering menginfeksi anak-anak di Papua.

Sebagai kesimpulan, malaria masih merupakan penyakit menular yang menjadi perhatian dunia, 
terutama di Provinsi Papua. Penyakit ini masih berdampak luas terhadap kualitas hidup dan ekonomi. Kejadian penyerta anemia serta gizi kurang merupakan salah satu hal yang harus dievaluasi. Diperlukan pemeriksaan lebih lanjut keadaan anemia dan gizi kurang pada anak yang menderita malaria sehingga diperlukan kerjasama berbagai pihak untuk mengatasi ini.

\section{Daftar pustaka}

1. Soedarmo SS, Garna H, Hadinegoro SR, Satari HI. Malaria. Dalam: Soedarmo SS, Garna H, Hadinegoro SR, Satari HI, penyunting. Buku Ajar Infeksi dan Pediatri Tropis. Edisi Kedua. Jakarta: Badan penerbit IDAI; 2010.h.408-37.
2. Badan penelitian dan pengembangan kesehatan. Riskesdas 2013. Kementrian Kesehatan RI; 2013.h.76-8.

3. Crookston BT, Alder SC, Boakye I, Merrill RM, Amuasi JH, Porucznik CA, dkk. Exploring the relationship between chronic undernutrition and asymptomatic malaria in Ghanaian children. Malar 2010;9:39.

4. Ditjen Pengendalian Penyakit Dan Penyehatan Lingkungan. Pedoman pentatalaksanaan kasus malaria di Indonesia. Departemen Kesehatan RI; 2008.h.1-8.

5. WHO. World malaria reports; 2014.h.12-14.

6. Maketa V, Mavoko HM, Luz RI, Zanga J, Lubiba J, Kalonji A, dkk . The relationship between plasmodium infection, anaemia and nutritional status in asymptomatic children aged under five years living in stable transmission zones in Kinshasa, Democratic Republic of Congo. Malaria Journal 2015;14:83. 